\title{
Student's mathematical connection ability through GeoGebra assisted project-based learning model
}

\author{
Ari Septian \\ Departement of Mathematics Education, Universitas Suryakancana, West Java, Indonesia \\ *Correspondence: ariseptian@unsur.ac.id \\ (C) The Author 2022
}

\begin{abstract}
Several previous studies related to mathematical connection abilities and GeoGebra-assisted project-based learning models, but this research focuses on improving students' mathematical connection ability in the Integral Calculus course. This study examines the improvement of mathematical connection abilities through a project-based learning model assisted by GeoGebra. The research method used was a quasi-experimental design with a pretest-posttest nonequivalent multiple group design. The population is students of the Mathematics Education Study Program at the University in West Java, Indonesia. 1A and 1B students, which are used as samples. The technique of taking the research subject uses purposive sampling. The instrument consisted of a mathematical connection ability test with three essay questions. The test in this study used a pretest and posttest students' mathematical connection ability and the Group Embedded Figure Test (GEFT). The data analysis technique used an independent sample t-test and a two-way ANOVA test. The results showed that the improvement of students' mathematical connection ability who obtained the GeoGebra-assisted project-based learning model was better than students who obtained the project-based learning model. There is no interaction effect of learning models and cognitive styles on the achievement and improvement of students' mathematical connection abilities. The implication of this research is to provide significant changes in student learning habits in integral calculus courses to use technology and foster high self-regulated learning. This research has implications for universities implementing project-based learning models combined with other technology applications in other subjects.
\end{abstract}

Keywords: GeoGebra; mathematical connection ability; project-based learning 


\section{Introduction}

The connection ability of students in connecting concepts that have been studied previously is a significant problem (Islam et al., 2020; Tasni \& Susanti, 2017). Some students still have difficulty in relating one concept to another. For example, in determining integrals, students must first understand the concept of algebra and the concept of integral calculus (Borji et al., 2018). Thus, the work process in answering questions becomes smooth and makes calculations easier. Findings also occurred in previous research, namely having difficulty linking concepts between mathematical topics (Rachmani, 2018; Song, 2018). Other findings in previous research said that students' mathematical connection abilities were still low in linking or connecting mathematical topics with other disciplines (Amalia et al., 2019; DirckinckHolmfeld, 2016).

Several studies on mathematical connection abilities at the university level have also been carried out. For example, research on mathematical connection abilities by Abidin and Jupri (2017); Ariawan and Nufus (2018) focus on the profile of mathematical connection abilities in students' cognitive styles in the Differential Calculus course. Research by Yolanda and Wahyuni (2020) focuses on improving mathematical connection ability through the application of Accelerated Learning Cycle Learning in Algebra and Trigonometry courses. Research by Rachmani (2018) focuses on comparing Improvement students' mathematical connection ability through web-assisted brain-based learning and ordinary learning in the Integral Calculus course. Research by Noto, Hartono, and Sundawan (2016) focuses on analyzing students' mathematical connection abilities in the Spatial Analytical Geometry course. Research by Hotipah and Pujiastuti (2020) focuses on analyzing mathematical connection abilities in the Spatial Analytical Geometry course.

In several previous studies, the improvement in mathematical connections was caused by student center learning, including using a project-based learning model (Dirckinck-Holmfeld, 2016; Maskur et al., 2020; Suherman et al., 2020). The project-based learning model has several advantages that make mathematics learning more exciting and make learning independent. Some of the advantages of project-based learning include: (1) Improvement motivation; (2) improve problem-solving skills; (3) enhance collaboration; (4) improve resource management skills; (5) improve activity; (6) improve skills in finding information; (7) encourage to develop communication skills; (8) providing experience in project organization; (9) providing experience in making time allocations to complete tasks; (10) providing real-world learning experiences; (11) make the learning atmosphere fun (Grant, 2002; Ratnasari et al.,2018). Combining learning models with the use of media and multimedia with Macromedia Flash and Geogebra offline applications on some mathematical materials can improve mathematical connection ability (Alfian et al., 2017; Hu et al., 2016; Purwanti et al., 2016; Septian \& Komala, 2019). The previous description hopes that project-based learning assisted by Geogebra can improve mathematical connection abilities.

Based on several previous studies related to mathematical connection abilities and GeoGebra-assisted project-based learning models, this research focuses on improving students' mathematical connection ability in the Integral Calculus course. The GeoGebra-assisted 
project-based learning model has not been widely used to become a novelty, or there is an element of novelty in this research. GeoGebra-assisted project-based learning models to improve mathematical connection ability in Integral Calculus courses is still rare. The urgency of existing research has not led to its relevance to achieving and improving mathematical connection ability. Therefore, this research is focused on filling the part of knowledge that has not been studied. This study examines the improvement of mathematical connection abilities through a project-based learning model assisted by GeoGebra.

\section{Methods}

The type of research used was a quantitative method. The research method used in this research is quasi-experimental. The quasi-experimental research design used in this study was in the form of "Pretest Posttest Nonequivalent Multiple Group Design," which involved two groups of students, namely experimental group 1 and experimental group 2 (Johnson, \& Christensen, 2003). Choosing the Pretest Posttest, Nonequivalent Multiple Group Design because it uses existing groups according to analysis needs. It was comparing several groups in determining which one is significantly better to measure the effectiveness of the learning model used and students' cognitive style. The population in this study were students of the Mathematics Education Study Program level 1 semester 2 for the 2018-2019 academic year. Two classes, namely experimental class 1 (Level 1A) and experimental class 2 (Level 1B), are used as samples.

The research subject's technique uses purposive sampling, a sampling method whose selection refers to a specific purpose. The sample selection was based on student characteristics, including students who had almost identical scores in differential calculus and basic mathematics, could use GeoGebra, had adequate facilities, and a level of participation. Data collection techniques by conducting pretest and posttest mathematical connection ability and Group Embedded Figure Test (GEFT). The instrument in this study consisted of a mathematical connection ability test and the GEFT. The data analysis technique used an independent sample t-test and a two-way ANOVA test.

\section{Results}

The two samples from experimental group 1 and experimental group 2 came from normally distributed populations and had the same or homogeneous variance. Then the two mean differences were then tested with independent samples t-test with SPSS 24. Based on Table 1, the results of the independent sample t-test obtained a significance value of $0.000<0.05$. Thus, it can be concluded that there is a difference between the average improvement in mathematical connection ability of experimental group 1 and experimental group 2. Table 1 shows that descriptively, experimental group 1 and experimental group 2 have different averages, namely 0.63 and 0.25 . Thus, it can be concluded that the improvement in mathematical connection ability achieved by students who applied the GeoGebra-assisted project-based learning model was better than the students who only applied the project-based learning model. 
Table 1. Results of independent samples t test data gain index mathematical connection ability

\begin{tabular}{ccc}
\hline $\mathbf{t}$ & df & Sig. (2-tailed) \\
\hline 5.650 & 43 & 0.000 \\
\hline
\end{tabular}

In analyzing the effect of the interaction of learning models and cognitive styles on Improvement students' mathematical connection ability, they will be tested through a two-way ANOVA with the assumption that the gain index data with four different categories come from a normally distributed population. The results of the normality test are presented in Table 2 .

Table 2. Normality test results for improvement mathematical connection ability between learning models and cognitive styles

\begin{tabular}{ccccc}
\hline \multirow{2}{*}{ Group } & \multirow{2}{*}{ Cognitive Style } & \multicolumn{3}{c}{ Kolmogorov-Smirnov } \\
\cline { 2 - 5 } & & Statistics & df & Sig. \\
\hline Experiment 1 & Field independent & 0.259 & 10 & 0.057 \\
\cline { 2 - 5 } & Field dependent & 0.143 & 12 & 0.200 \\
\hline \multirow{2}{*}{ Experiment 2} & Field independent & 0.164 & 8 & 0.200 \\
\cline { 2 - 5 } & Field dependent & 0.132 & 15 & 0.200
\end{tabular}

Based on the normality test results contained in Table 2, the significance value for all groups $>0.05$ was obtained, then $\mathrm{H} 0$ was accepted. Thus, it can be concluded that the entire group sample came from a normally distributed population. The homogeneity test results using Levene's test are to obtain a value of $F=1.991$ and a value of sig. $=0.130$. Thus, it can be concluded that the data is homogeneous or has the same variance. Furthermore, it will be tested using Anova Two Paths. The hypothesis being tested is an interaction effect of learning models and students' cognitive styles on Improvement students' mathematical connection abilities.

In Table 3, it is found that: (1) on the learning model factor; the significance value is $<0.05$, then $\mathrm{H} 0$ is rejected. It shows a significant direct influence of learning model factors on Improvement students' mathematical connection abilities; (2) on the cognitive style factor, obtained a significance value $>0.05$, then $\mathrm{H} 0$ is accepted. It shows no significant direct effect of cognitive style factors on Improvement students' mathematical connection abilities, and (3) the effect of the interaction obtained a significance value $>0.05$ so that $\mathrm{H} 0$ is accepted. Thus, it can be concluded that there is no interaction effect of learning models and cognitive styles on Improvement students' mathematical connection abilities.

Table 3. Interaction test results between learning models and cognitive styles on improvement mathematical connection ability

\begin{tabular}{lccccc}
\hline \multicolumn{1}{c}{ Source } & $\begin{array}{c}\text { Sum of } \\
\text { Squares }\end{array}$ & df & Average Square & F & Sig. \\
\hline Learning model & 1.598 & 1 & 1.598 & 33.949 & 0.000 \\
\hline Cognitive style & 0.023 & 1 & 0.023 & 0.493 & 0.487 \\
\hline Interaction & 0.125 & 1 & 0.125 & 2.654 & 0.111 \\
\hline
\end{tabular}

Adjusted R Square x $100 \%=43 \%$ 


\section{Discussion}

The achievement and improvement of students' mathematical connection ability who apply the GeoGebra-assisted project-based learning model are because of the GeoGebra-assisted Projectbased learning model. It is a learning model that provides opportunities for students to find information according to phenomena related to Integral Calculus, plan, implement, display project results in GeoGebra form, and evaluate the project results (Septian et al., 2020). In addition, student knowledge improves due to experience when learning, interaction, and communication occur between students and between students and lecturers (Kennedy et al., 2016).

The group activities in the implementation of project-based learning assisted by GeoGebra occur dynamically and can elaborate on the results of their work. According to the theory from Creighton (1916), Dirckinck-Holmfeld (2016) states that project-based learning provides experiences, activities, interactions between students, interactions between students and teachers/lecturers. Several learning theories are applied to the GeoGebra-assisted projectbased learning model, namely the cognitive development theory of Piaget and Bruner. According to Piaget (McLeod, 2015), cognitive development is largely determined by children's manipulation and active interaction with the environment. In line with that, Conway (2007) argues that knowledge is obtained through children's active participation in learning, learning experiences, and experimenting with problems. In the end, the achievement and improvement of students' mathematical connection ability who applied the GeoGebra-assisted project-based learning model were better than students who only applied the project-based learning model.

In this era, technology has become one of the requirements in work. Educators are required to master teaching materials, learning models, and technology-based multimedia (Hallal et al., 2016; Mohd et al., 2020). The importance of technology-based multimedia has a positive impact on the learning process and student learning outcomes (Septian et al., 2021; Song, 2018). GeoGebra is a software that can be used for free and easily and is complete in algebra, geometry, statistics, and others (Velázquez \& Méndez, 2021; Poon \& Wong, 2017; Yildiz, 2018). GeoGebra can also be used in integral calculus material; students feel helped by this GeoGebra. The problem of making graphs that became the background of the problem when found in observations was resolved well. For example, students can create a graph of a mathematical equation or data (Caligaris et al., 2015).

The research findings show no interaction effect of learning models and cognitive styles on Improvement students' mathematical connection abilities. It is in line with the findings from the research of

Firdausi, Inganah, and Rosyadi (2018) state that the improvement in mathematical connection ability is not influenced by the interaction of learning model variables and cognitive styles. Based on this explanation, it can be concluded that the learning model factors and cognitive style factors together have no direct effect on improving students' mathematical connection abilities. It means that there is no difference in the average improvement in students' mathematical connection abilities in terms of interaction factors between learning models and cognitive styles.

The difference in students' mathematical connection abilities can be explained by the variability of the learning model factors, cognitive style factors, and other factors that influence the rest. No interaction effect of learning models and cognitive styles on improving students' mathematical connection ability is because students with field-independent cognitive styles are 
either given treatment with the GeoGebra-assisted project-based learning model or those treated with project-based learning models already have the habits they do. Some of them can analyze to separate objects from the surrounding environment so that their perceptions are not affected when the environment changes. In addition, the majority of the group of students with a fieldindependent cognitive style improved students' mathematical connection abilities with good criteria.

The findings in this study also show the influence of the learning model on Improvement students' mathematical connection abilities. The application of the GeoGebra-assisted projectbased learning model or those that do not use GeoGebra positively impacts motivation, activity, independent learning, and social interaction. In following Dewey (2012), student center learning motivates students in the learning process. In learning, the project-based learning model provides experience, and interactions occur between students. In another theory, according to Piaget (Alamolhodaei, 2009; McLeod, 2015), cognitive development is largely determined by the manipulation and active interaction of children with the environment. In line with that, he argues that knowledge is obtained through children's active participation in learning, learning experiences, and experimenting with problems that occur (Barnard et al., 2018). In the end, students' mathematical connection ability experienced a significant improvement, both applying the GeoGebra-assisted project-based learning model or only applying the project-based learning model.

The following finding is that cognitive style improves students' mathematical connection abilities. Students with field-independent cognitive styles have better scores than fielddependent ones. It is in line with Ariawan and Nufus's (2018) findings, which concluded that students with field-independent cognitive styles were better than field-dependent cognitive styles. Starting from the learning process based on projects that each group or individual independently carries out, it is an improvement distinguishing the ability of mathematical connections in different cognitive styles. Students with field-independent cognitive styles tend to be able to solve problems independently without waiting for others so that their knowledge improves and leads to the achievement of better mathematical connection abilities. According to the theory of Witkin in Udiyono and Yuwono (2018), the influence of student cognitive style is more on the habit of learning independently or depending on others. The characteristic of field-independent is that students do not depend on the learning environment in the classroom and do not depend on other students when learning. Meanwhile, the characteristic of fielddependent causes students to be very and always dependent on the learning environment and other people (Ma'rufi et al., 2018; Vendiagrys \& Junaedi, 2015).

The other factors that influence the improvement of mathematical connection ability are students' prerequisite skills such as differential calculus, basic mathematics, two-variable algebraic equations, and geometry (Korenova, 2017; Poon \& Wong, 2017). The ability of mathematical connections is influenced by other factors, such as the ability of prerequisites that are still not qualified. The previous material must be mastered well to make working on the questions more effortless. Another factor determining the ability of mathematical connections is the mastery of geometry and the ability to solve everyday problems (Amaliyah \& Mahmud, 2018; Kennedy et al., 2016). 


\section{Conclussion}

The improvement of students' mathematical connection ability who received the GeoGebraassisted project-based learning model was better than the students who received the projectbased learning model. There was no interaction effect between the learning model and cognitive style (field-independent and field-dependent) on improving students' mathematical connection ability. The limitation of this research is that it has not specifically examined the prerequisite factors that determine the improvement of students' mathematical connection abilities. In addition, the problem of time and facilities in the implementation of project-based learning is an obstacle, so there need to be improvements in the future that are somewhat more planned.

\section{Conflict of Interest}

I as the author declare that there is no conflict of interest regarding the publication of this manuscript. In addition, the ethical issues, including plagiarism, misconduct, data fabrication and/or falsification, double publication and/or submission, and redundancies have been completely by the authors.

\section{References}

Abidin, Z., \& Jupri, A. (2017). The use of multiliteration model to improve mathematical connection ability of primary school on geometry. IJAEDU-International E-Journal of Advances in Education, 3(9), 603-610. https://doi.org/10.18768/ijaedu.370429

Alamolhodaei, H. (2009). A working memory model applied to mathematical word problem solving. Asia Pacific Education Review, 10(2), 183-192. https://doi.org/10.1007/s12564009-9023-2

Alfian, M. H., Dwijanto, D., \& Sunarmi, S. (2017). Effectiveness of probing-prompting learning models with scaffolding strategy to mathematic creative thinking ability and enthusiasm. Unnes Journal of Mathematics Education, 6(2), 249-257.

Amalia, R., Lutfiyah, L., \& Permatasari, V. A. (2019). Deskripsi kemampuan koneksi matematis siswa berkemampuan tinggi dalam menyelesaikan soal cerita [Description of students' mathematical connection abilities with high abilities in solving story problems]. JIPMat, 4(1), 44-52. https://doi.org/10.26877/jipmat.v4i1.3664

Amaliyah AR. R., \& Mahmud, N. (2018). Analisis kemampuan representasi matematis dalam pemecahan masalah geometri serta faktor-faktor yang mempengaruhinya [Analysis of mathematical representation ability in solving geometric problems and the factors that influence it]. Jurnal Review Pembelajaran Matematika, 3(2), 146-160. https://doi.org/10.15642/jrpm.2018.3.2.146-160

Ariawan, R., \& Nufus, H. (2018). Profil kemampuan koneksi matematis mahasiswa dalam menyelesaikan masalah pada mata kuliah kalkulus I ditinjau berdasarkan level kemampuan akademik [The profile of students' mathematical connection abilities in solving problems in the calculus I course is reviewed based on the level of academic ability]. Jurnal Prinsip Pendidikan Matematika, 1(1), 16-22. https://doi.org/10.33578/prinsip.v1i1.15

Barnard, L., Lan, W. Y., Crooks, S. M., Alexiou, A., Paraskeva, F., Bempechat, J., ... Champakaew, W. (2018). Educational psychology in practice: Theory, research and practice in educational psychology the impact of different teaching methods on students' 
arithmetic and self-regulated learning skills. Learning and Instruction, 7(2), 37-41.

Borji, V., Alamolhodaei, H., \& Radmehr, F. (2018). Application of the APOS-ACE theory to improve students' graphical understanding of derivative. Eurasia Journal of Mathematics, Science and Technology Education, 14(7), 2947-2967. https://doi.org/10.29333/ejmste/91451

Caligaris, M. G., Schivo, M. E., \& Romiti, M. R. (2015). Calculus \& GeoGebra, an interesting partnership. Procedia - Social and Behavioral Sciences, 174, 1183-1188. https://doi.org/10.1016/j.sbspro.2015.01.735

Conway, T. R. (2007). Jerome Bruner - Learning by Discovery. In Horn, R.A. (Ed.), The Praeger Handbook of Education and Psychology (Eds. 1), p. 59. Praeger Pub.

Creighton, J. E. (1916). Democracy and Education by John Dewey. The Philosophical Review, 25(5), 735-741. https://doi.org/10.2307/2178611

Dewey, J. (2012). Education and Democracy in the World of Today (1938). Schools, 9(1), 96100. https://doi.org/10.1086/665026

Dirckinck-Holmfeld, L. (2016). Networked learning and problem and project based learning how they complement each other. Proceedings of the 10th International Conference on Networked Learning 2016, 193-199.

Firdausi, M., Inganah, S., \& Putri Rosyadi, A. A. (2018). Kemampuan koneksi matematis siswa sekolah menengah pertama berdasarkan gaya kognitif [Mathematical connection ability of junior high school students based on cognitive style]. MaPan: Jurnal Matematika dan Pembelajaran, 6(2), 237-249. https://doi.org/10.24252/mapan.2018v6n2a9

Grant, M. M. (2002). Getting a grip on project-based learning: Theory, cases and recommendations. Meridian: A Middle School Computer Technologies Journal, 5, 1-17.

Hallal, R., Hellmann, L., Sandmann, A., Carvalho, A. P., Reinaldo, F., \& Hotz, C. (2016). GeoGebra in teaching of Differential Integral Calculus I. Espacios, 37(20).

Hotipah, P., \& Pujiastuti, H. (2020). An analysis of mathematical connection ability in cubes and cuboids learning materials based on gender differences. Desimal: Jurnal Matematika, 3(2), 137-142. https://doi.org/10.24042/djm.v3i2.6118

Hotipah, P., \& Pujiastuti, H. (2020). Mathematical representation ability by using project based learning on the topic of statistics. Journal on Mathematics Education, 3(1), 69-79. https://doi.org/10.24042/tadris.v3i1.2535

Hu, R., Wu, Y. Y., \& Shieh, C. J. (2016). Effects of virtual reality integrated creative thinking instruction on students' creative thinking abilities. Eurasia Journal of Mathematics, Science and Technology Education, 12(3), 477-486. https://doi.org/10.12973/eurasia.2016.1226a

Johnson, R. B., \& Christensen, L. (2003). Quantitative, qualitative, and mixed research. Educational Researcher, 33(7), 14-26. https://doi.org/10.3102/0013189X033007014

Kennedy, J., Lee, E., \& Fontecchio, A. (2016). STEAM approach by integrating the arts and STEM through origami in K-12. 2016 IEEE Frontiers in Education Conference (FIE), 1-5. https://doi.org/10.1109/FIE.2016.7757415

Korenova, L. (2017). GeoGebra in teaching of primary school mathematics. International Journal for Technology in Mathematics Education, 24(3), 155-160.

Ma'rufi, Pasandaran, R. F., \& Yogi, A. (2018). Analisis pemahaman konsep geometri mahasiswa ditinjau dari gaya kognitif field dependent dan field independent [Analysis of students' understanding of geometry concepts in terms of field dependent and field independent cognitive styles]. Proximal: Jurnal Penelitian Matematika dan Pendidikan Matematika, 1(2), 56-67. https://journal.uncp.ac.id/index.php/proximal/article/view/1053

Maskur, R., Sumarno, Rahmawati, Y., Pradana, K., Syazali, M., Septian, A., \& Palupi, E. K. (2020). The effectiveness of problem based learning and aptitude treatment interaction in 
improving mathematical creative thinking skills on curriculum 2013. European Journal of Educational Research, 9(1), 375-383. https://doi.org/10.12973/eu-jer.9.1.375

McLeod, S. A. (2015). Jean Piaget: Cognitive theory. Developmental Psychology, 1-7. https://www.simplypsychology.org/piaget.html

Mohd, C. K. N. C. K., Shahbodin, F., Sedek, M., \& Samsudin, M. (2020). Game based learning for autism in learning mathematics. International Journal of Advanced Science and Technology, 29(5), 4684-4691.

Noto, M. S., Hartono, W., \& Sundawan, D. (2016). Analysis of students mathematical representation and connection on analytical geometry subject. Infinity Journal, 5(2), 99107. https://doi.org/10.22460/infinity.v5i2.216

Poon, K. K., \& Wong, K. L. (2017). Pre-constructed dynamic geometry materials in the classroom - how do they facilitate the learning of 'Similar Triangles'? International Journal of Mathematical Education in Science and Technology, 48(5), 735-755. https://doi.org/10.1080/0020739X.2016.1264636

Purwanti, R. D., Pratiwi, D. D., \& Rinaldi, A. (2016). Pengaruh pembelajaran berbantuan GeoGebra terhadap pemahaman konsep matematis ditinjau dari gaya kognitif [The effect of GeoGebra-assisted learning on understanding mathematical concepts in terms of cognitive style]. Al-Jabar: Jurnal Pendidikan Matematika, 7(1), 115-122. https://doi.org/10.24042/ajpm.v7i1.137

Rachmani, N. (2018). Kemampuan koneksi matematis mahasiswa calon guru pada brain-based learning berbantuan web. [The mathematical connection ability of prospective teacher students in web-assisted brain-based learning] Kreano: Jurnal Matematika KreatifInovatif, 9(2), 204-214.

Ratnasari, N., Tadjudin, N., Syazali, M., Mujib, M., \& Andriani, S. (2018). Project based learning (PJBL) model on the mathematical representation ability. Tadris: Jurnal Keguruan dan Ilmu Tarbiyah, 3(1), 47-53. https://doi.org/10.24042/tadris.v3i1.2535

Septian, A., Darhim, \& Prabawanto, S. (2020). Mathematical representation ability through GeoGebra-assisted project-based learning models. Journal of Physics: Conference Series. https://doi.org/10.1088/1742-6596/1657/1/012019

Septian, A., Darhim, D., \& Prabawanto, S. (2021). The development of calculus teaching materials using GeoGebra. IndoMath: Indonesia Mathematics Education, 4(1), 1-10. https://doi.org/10.30738/indomath.v4i1.7831

Septian, A., \& Komala, E. (2019). Kemampuan koneksi matematik dan motivasi belajar siswa dengan menggunakan model problem-based learning (PBL) berbantuan GeoGebra di SMP [Mathematical connection ability and student motivation to learn by using problembased learning (PBL) model assisted by GeoGebra in junior high school]. PRISMA, 8(1), 1-13. https://doi.org/10.35194/jp.v8i1.438

Sholekah, L. M., Anggreini, D., \& Waluyo, A. (2017). Analisis kesulitan siswa dalam menyelesaikan soal matematika ditinjau dari koneksi matematis materi limit fungsi [Analysis of students' difficulties in solving math problems in terms of the mathematical connection of the limit function material]. WACANA AKADEMIKA: Majalah Ilmiah Kependidikan, 1(2), 151-164. https://doi.org/10.30738/wa.v1i2.1413

Song, Y. (2018). The calculus teaching based on MATLAB. Journal of Advanced Oxidation Technologies, 21(2), 130-138. https://doi.org/10.26802/jaots.2018.09781

Suhandri, S., Nufus, H., \& Nurdin, E. (2017). Profil kemampuan koneksi matematis mahasiswa dalam menyelesaikan masalah matematika berdasarkan level kemampuan akademik [Profile of students' mathematical connection abilities in solving math problems based on their level of academic ability]. Jurnal Analisa, 3(2), 115-129. https://doi.org/10.15575/ja.v3i2.2012

Suherman, Prananda, M. R., Proboningrum, D. I., Pratama, E. R., Laksono, P., \& Amiruddin. 
(2020). Improving higher order thinking skills (HOTS) with project based learning (PjBL) model assisted by GeoGebra. Journal of Physics: Conference Series, 1467(1), Article 012027. https://doi.org/10.1088/1742-6596/1467/1/012027

Tasni, N., \& Susanti, E. (2017). Membangun koneksi matematis siswa dalam pemecahan masalah verbal [Building students' mathematical connections in verbal problem solving]. Beta Jurnal Tadris Matematika, 10(1), 100-108. https://doi.org/10.20414/betajtm.v10i1.108

Udiyono, \& Yuwono, M. R. (2018). The correlation between cognitive style and students' learning achievement on geometry subject. Infinity Journal, 7(1), 35-44. https://doi.org/10.22460/infinity.v7i1.p35-44

Velázquez, F. D. C., \& Méndez, G. M. (2021). Application in augmented reality for learning mathematical functions: A study for the development of spatial intelligence in secondary education students. Mathematics, 9(4), 1-19, Article 369. https://doi.org/10.3390/math9040369

Vendiagrys, L., \& Junaedi, I. (2015). Analisis kemampuan pemecahan masalah soal setipe timss berdasarkan gaya kognitif siswa pada pembelajaran model problem based learning [Analysis of problem-solving abilities of the type of timss based on students' cognitive style in problem-based learning model learning]. Unnes Journal of Mathematics Education Research, 4(1), 34-41.

Yildiz, H. (2018). The development process of a mathematic teacher's technological pedagogical content knowledge. European Journal of Educational Research, 7(1), 9-29. https://doi.org/10.12973/eu-jer.7.1.9

Yolanda, F., \& Wahyuni, P. (2020). Peningkatan kemampuan koneksi matematis mahasiswa melalui pembelajaran matematika kontekstual [Improving students' mathematical connection skills through contextual mathematics learning]. ANARGYA: Jurnal Ilmiah Pendidikan Matematika, 3(1), 1-7. https://doi.org/10.24176/anargya.v3i1.4750 